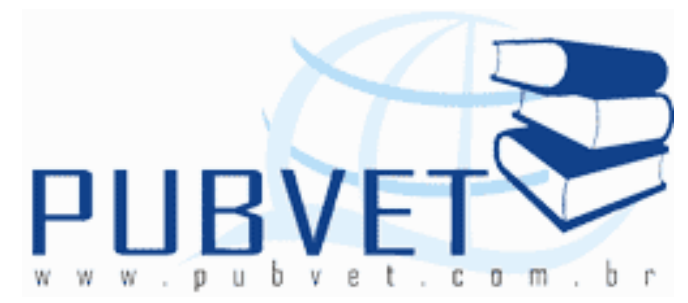

PUBVET, Publicações em Medicina Veterinária e Zootecnia.

Disponível em: <https://doi.org/10.31533/pubvet.v02n10a375>.

\title{
Enumeração de coliformes termotolerantes em pescados frescos e congelados
}

Vera Lúcia Mores Rall ${ }^{1}$, Karen Franco de Godoi Cardoso² ${ }^{2}$ Camila Xavier ${ }^{3}$

${ }^{1}$ Departamento de Microbiologia e Imunologia do Instituto de Biociências da UNESP/Botucatu.

2 Departamento de Produção Animal da Faculdade de Medicina Veterinária e Zootecnia - UNESP/Botucatu

3 Departamento de Microbiologia e Imunologia do Instituto de Biociências da UNESP/Botucatu.

\section{Resumo}

A carne do peixe é um alimento extremamente perecível e requer adequadas condições sanitárias desde o momento de sua captura (pesca) até a preparação, comercialização e consumo. Diante disso, foi realizada a enumeração de coliformes termotolerantes em 70 amostras de peixes, sendo 37 congeladas e 33 de peixe fresco, comercializados na cidade de Botucatu, segundo metodologia da APHA. A presença de coliformes termotolerantes ocorreu em $7(21,2 \%)$ das 33 amostras de peixe fresco analisadas, com variações de < 3 a $93 \mathrm{NMP} / \mathrm{g}$. Já nas amostras congeladas, $4(10,8 \%)$ das 37 
amostras foram positivas para esse indicador, em concentrações que variaram de $<3$ a $>2,4 \times 10^{3} \mathrm{NMP} / \mathrm{g}$.

Palavras - chave: pescados, qualidade, coliformes termotolerantes

\title{
List of thermotolerant coliforms in fresh and frozen fish
}

\begin{abstract}
The meat of the fish is a highly perishable food and requires adequate sanitary conditions since the time of their catch (fish) to the preparation, marketing and consumption. Given that, he was held the enumeration of thermotolerant coliforms in 70 samples of fish, frozen with 37 and 33, fresh fish, marketed in the city of Botucatu, according methodology of APHA. The presence of coliform thermotolerant occurred in $7(21.2 \%)$ from 33 samples of fresh fish examined, with variations of $<3$ to $93 \mathrm{NMP} / \mathrm{g}$. Already in the frozen samples, $4(10.8 \%)$ from 37 samples were positive for this indicator, at concentrations ranging from $<3$ to $>2.4 \times 10^{3} \mathrm{NMP} / \mathrm{g}$.
\end{abstract}

Key - Words: fish, quality, thermotolerant coliforms

\section{Introdução}

O peixe e seus derivados têm uma grande importância na dieta de todo o mundo (Feldhusen, 2000). Ele contribui com $1 / 4$ da oferta mundial de proteína de origem animal (Kent, 1997; Josupeit, 2004). Na Europa e na Ásia, o pescado é a principal fonte de proteína animal (Huss et al., 2000). As características nutricionais dos frutos do mar e peixes fazem deles um alimento benéfico à saúde, pois é rico em proteínas, vitaminas, micronutrientes e gorduras insaturadas.

A carne do peixe é um alimento extremamente perecível e requer adequadas condições sanitárias desde o momento de sua captura (pesca) até a preparação, comercialização e consumo. Durante os estágios de 
armazenamento, transporte, comercialização ou nas etapas do processamento industrial onde haja espera é fundamental que o pescado permaneça sempre refrigerado (Ceredas e Sanches, 1983).

Imediatamente após a retirada da água, o peixe começa a sofrer deterioração. Semelhante a qualquer carne, o peixe sofre autólise, oxidação e atividade bacteriana. A diferença entre as demais carnes e a carne de peixe é que os músculos dos peixes são mais susceptíveis ao processo autolítico do que os músculos dos mamíferos. Deste modo, a reação é mais rápida e menos ácida favorecendo a proliferação bacteriana (Vieira et al., 2004). Além da autólise, as características nutricionais do peixe fornecem um meio nutritivo que facilita ainda mais o desenvolvimento das bactérias (Munkundun et al. 1986).

O pescado pode ser um veiculador de diversos microrganismos patogênicos para o homem. Essa contaminação pode ocorrer nas várias etapas do processamento conforme Tabela 1. Este quadro foi elaborado com base nos princípios da HACCP para a atividade de pesca.

Durante o beneficiamento, o peixe pode ser eviscerado, preparado em files e postas, onde pode ocorrer contaminação se não forem adotadas boas praticas de manipulação, higienização e sanitização (Huss et al., 2000). A água em contato com os alimentos de origem animal, inclusive a usada para higienização de equipamentos e indústrias, deve ter o mesmo padrão microbiológico e de potabilidade da água para consumo humano. As normas legais exigem que a água usada pelas indústrias apresente ausência de coliformes termotolerantes (Brasil, 2003).

Os coliformes termotolerantes são um subgrupo dos coliformes totais com capacidade de fermentar a lactose e produzir gás quando incubados a uma temperatura de $45^{\circ} \mathrm{C}$ por no máximo 48 horas. A Escherichia coli tem como habitat exclusivo, o intestinal humano. Por apresentar uma origem estritamente fecal são utilizadas como indicador de contaminação fecal (Silva et al., 2001; Franco \& Landgraf, 2003). 
Tabela 1 - Perigos e Pontos de Controle Crítico (PCC) na produção de pescado fresco e congelado

\begin{tabular}{|c|c|c|}
\hline Fluxo do produto & Perigo & Medida preventiva \\
\hline Peixe vivo & Contaminação & $\begin{array}{l}\text { Vigilância do } \\
\text { ambiente }\end{array}$ \\
\hline $\begin{array}{c}\text { Captura e } \\
\text { manuseamento }\end{array}$ & Proliferação bacteriana & PCC \\
\hline Refrigeração & Proliferação bacteriana & PCC \\
\hline \multirow[t]{2}{*}{ Descarga } & \multirow{2}{*}{$\begin{array}{l}\text { Excesso de contaminação e/ou } \\
\text { proliferação bacteriana }\end{array}$} & $\begin{array}{c}\text { Higiene no } \\
\text { manuseamento }\end{array}$ \\
\hline & & PCC \\
\hline $\begin{array}{l}\text { Recepção da matéria } \\
\text { prima no } \\
\text { estabelecimento }\end{array}$ & $\begin{array}{l}\text { Produto de qualidade inferior } \\
\text { admitido no fabrico }\end{array}$ & $\begin{array}{c}\text { Verificar a fonte de } \\
\text { aprovisionamento } \\
\text { análise sensorial }\end{array}$ \\
\hline \multicolumn{3}{|l|}{$\begin{array}{l}\text { Armazenagem da } \\
\text { matéria prima }\end{array}$} \\
\hline \multicolumn{3}{|l|}{ Lavagem } \\
\hline "Filetagem" & Presença de parasitas & $\begin{array}{l}\text { Inspeção visual com } \\
\text { iluminação }\end{array}$ \\
\hline \multicolumn{3}{|l|}{ "Despelagem" } \\
\hline \multirow{4}{*}{$\begin{array}{l}\text { Todas as etapas do } \\
\text { processamento }\end{array}$} & Proliferação bacteriana & PCC \\
\hline & \multirow{3}{*}{ Contaminação } & Higiene da fabrica \\
\hline & & Qualidade da água \\
\hline & & Medidas sanitárias \\
\hline Embalagem & Deterioração (oxidação) & $\begin{array}{c}\text { Material de } \\
\text { embalagem a vácuo }\end{array}$ \\
\hline Refrigeração & Proliferação bacteriana & PCC \\
\hline Congelamento & Deterioração química/autolítica & PCC \\
\hline
\end{tabular}

A resolução RDC $n^{\circ} 12$ da Agência Nacional de Vigilância Sanitária, de 12 de janeiro de 2001, não estabelece enumeração de coliformes termotolerantes como parâmetro microbiológico em pescados, no entanto, essa pesquisa foi realizada pelo fato desses microrganismos serem utilizados como indicadores da presença de bactérias patogênicas. Assim sendo, o 
objetivo deste trabalho foi a enumeração de coliformes termotolerantes em amostras de pescados comercializados na cidade de Botucatu/SP.

\section{Material e Métodos}

\subsection{Coleta das Amostras para Análise}

Foram coletadas 70 amostras de peixes, sendo 37 congeladas e 33 de peixe fresco em supermercados e peixarias do município de Botucatu/SP, no período de março a outubro de 2007. As amostras foram mantidas dentro das próprias embalagens vendidas e armazenadas dentro de bolsas térmicas com gelo e termômetro para serem transportadas para o Laboratório de Microbiologia de Alimentos da UNESP-Botucatu. As análises foram realizadas num prazo máximo, entre a coleta e a chegada no laboratório, de duas horas. Entre as amostras coletadas estavam peixes frescos e peixes congelados dentro do prazo de validade.

\subsection{Análise Microbiológica}

\subsubsection{Preparo das amostras e suas diluições}

As análises foram realizadas de acordo com o American Public Health Association (2001). Para tal, 25 gramas de amostra foram pesados e homogeneizados em $225 \mathrm{ml}$ de água peptonada tamponada, em sacos plásticos apropriados, que foram levados ao Stomacher Lab Blender 400 por 30 segundos. A partir desta diluição inicial de $10^{-1}$, foram preparadas várias diluições decimais, utilizando-se o mesmo diluente.

\subsubsection{Determinação do Número Mais Provável (NMP) de coliformes termotolerantes}

Para a determinação do Número Mais Provável de colifomes termotolerantes foi utilizado o método descrito por Kornacki \& Johnson (2001), onde cada diluição da amostra foi inoculada em volumes de $1 \mathrm{ml}$, em série de 
três tubos por diluição, contendo $10 \mathrm{ml}$ de caldo lauril sulfato (Difco) com um tubo de Durham invertido. Os tubos foram incubados a $35^{\circ} \mathrm{C}$, por 24-48 horas. Nos inóculos positivos foi observada a produção de gás no tubo de Durham. A seguir, três alçadas de cada tubo positivo foram repicadas em tubos de ensaio contendo $5 \mathrm{ml}$ de caldo E.C. (Difco), para a confirmação de coliformes termotolerantes (CT) que foram incubados a $45^{\circ} \mathrm{C}$, por 24 horas. Após o período de incubação, foi realizada a leitura pela observação da presença de gás no tubo de Durham invertido. A seguir, utilizou-se a tabela de Hoskins para determinação do Número Mais Provável, NMP, e foram calculados os NMP de CT por grama de amostra analisada.

\section{Resultados e Discussão}

A presença de coliformes termotolerantes (CT) ocorreu em 7 (21,2\%) das 33 amostras de peixe fresco analisadas, com variações de $<3$ a $93 \mathrm{NMP} / \mathrm{g}$. Já nas amostras congeladas, $4(10,8 \%)$ das 37 amostras foram positivas para esse indicador, em concentrações que variaram de $<3$ a $>2,4 \times 10^{3} \mathrm{NMP} / \mathrm{g}$.

Ocorreu um maior número de amostras de peixe fresco contaminadas por coliformes termotolerantes $(21,2 \%)$ em relação ao congelado $(10,8 \%)$, pois em baixas temperaturas há uma redução ou inibição do crescimento de microrganismos. Entre as amostras de peixes, fresco ou congelado, coletadas como filé ou posta, observou-se que a contaminação por bactérias termotolerantes eram maiores em filé, pois o preparo deste inclui evisceração, retirada da pele e "filetagem". O preparo do pescado em filé exige maior manipulação quando comparado ao peixe fatiado em postas, assim como relataram Munkundun et al. (1986) e Vieira et al. (2004).

No Brasil, a contaminação de alimentos é um problema sério de saúde pública. A análise microbiológica dos alimentos envolvidos em surtos de intoxicação alimentar, juntamente com avaliações sanitárias e epidemiológicas, são ferramentas indispensáveis para elucidar a origem e as condições que possibilitaram a veiculação dos microrganismos e seus produtos. Desta forma, 
os estudos de surtos apresentam relevante importância para a saúde pública, mostrando a necessidade da implantação de práticas que garantam a qualidade dos alimentos produzidos.

\section{Conclusão}

Apesar da resolução RDC n¹2 da Agência Nacional de Vigilância Sanitária, de 12 de janeiro de 2001, não estabelecer enumeração de coliformes termotolerantes como parâmetro microbiológico em pescados, a contaminação destes por esse grupo de microrganismo pode representar risco a saúde de seus consumidores.

\section{Referências Bibliográficas}

BRASIL. Ministério da Saúde. Secretaria de Vigilância Sanitária. Regulamento Técnico sobre "Condições Higiênico-Sanitárias e de Boas Práticas de Fabricação para Estabelecimentos Produtores/Industrializadores de Alimentos. Aprovado a Portaria no 326, de 30 de julho de 1997 e regulamentado pela Resolução RDC no 175, 08 de julho de 2003. Brasília, DF, 2003

BRASIL. Agência Nacional de Vigilância Sanitária. Resolução RDC $n^{\circ} 12$, de 02 de janeiro de 2001. Aprova o Regulamento Técnico sobre os padrões microbiológicos para alimentos. ANVISA. Disponível em< http://www.anvisa.gov.br/ > Acesso em: 8 mar.2007

CEREDA, MP; SANCHES, L. Manual de armazenamento e de embalagem de produtos agropecuários. Botucatu: Fundação de Estudos e Pesquisa Agrícolas e Florestais, 1983, 263p. FRANCO, BDGM; LANGRAF, M. Microbiologia de Alimentos. São Paulo: Atheneu, 2003

FELDHUSEN, F. The role of seafood in bacterial foodborne diseases. Microbes and Infections, v.2, p. 1651-1660, 2000.

HUSS, H. H.; REILLY, A.; Embrakeb, P.K.B. Prevention and control of hazard in seafood. Food Control, v. 11, p. 149-156, 2000.

JOSUPEIT, $H$. Future demand of fish and impact on trade, 2004. Disponível em <http://www.globefish.org> Acesso em: 20 ago. 2007

KENT, G. Fisheries, food security and the poor. Food Policy Journal, v. 22, p. 393-404, 1997.

KORNACKI, J.L.; JOHNSON, J.L. Enterobacteriaceae, coliforms, and Escherichia coli as quality and safety indicators. In: DOWNES F. P; ITO, K. (Eds). Compendium of Methods for the Microbiological Examination of Foods. Washington: Apha, 69-80, 2001. 
Rall, V.L.M., Cardoso, K.F.G. e Xavier, C. Enumeração de coliformes termotolerantes em pescados frescos e congelados. PUBVET, Londrina, V. 2, N. 39, Art\#375, Out1, 2008.

MUNDUNKUN, M.K.; ANTONY, P.D.; NAIR; N.R. A review on autolysis in fish. Fisheries Research, v.4, p. 259-269, 1986.

SILVA, N; JUNQUEIRA, VCA; Silveira, NF de A. Manual de métodos de analise microbiológico de alimentos. 2 edição. São Paulo: Varela, 2001, 295p.

VIEIRA, R.H.S.F. et al. Microbiologia, higiene e qualidade do pescado. São Paulo: Livraria Varela, 2004, 380p 